\title{
Perancangan Robot Line Follower Pemisah Benda Berdasarkan Warna Berbasis Mikrokontroler ATMega16
}

\author{
Muhammad Arif Prayudi*1, Edy Victor Haryanto Sianturi², \\ Iwan Fitrianto Rahmad ${ }^{3}$, Khairul Ummi ${ }^{4}$ \\ ${ }_{1,2,3,4}$ STMIK Potensi Utama \\ E-mail: ${ }^{* 1}$ arief_ahmad1990@yahoo.com, ${ }^{2}$ edyvictor@gmail.com, \\ 3iwanfitrah@yahoo.com, ${ }^{4}$ ummi@potensi-utama.ac.id
}

\begin{abstract}
Abstrak
Line Follower Robot adalah sebuah robot otomatis yang dapat mengikuti garis yang dibuat dengan menggunakan bahan yang berwarna gelap (hitam) yang didukung oleh rangkain komponen elektronika yang dilengkapi dengan roda dan digerakan oleh motor. Pengendalian kecepatan sangat bergantung pada bata putaran dan pergesekan antara ban robot dengan lantainya. Robot tersebut dirancang untuk bernavigasi dan bergerak secara otomatis mengikuti sebuah alur garis yang dibuat. Untuk membaca garis, robot dilengkapi dengan sensor optik yang diletakkan diujung depan dari robot tersebut. Line Follower Robot ini memiliki jenis dan bentuk serta memiliki beberapa sistem penggerak dan pengendali sebagai pengatur kinerja yang beraneka ragam sesuai dengan kreatifita pembuatnya. Pada perancangan proyek line follower robot kali ini akan dibahas tentang pemisah warna benda dan dianalisi lebih dalam terhadap faktor suatu kecepatan robot dengan gerakan motor yang dikontrol oleh pengendali Prorportional Integral Derivative (PID) sehingga gerakan robot dapat dinamis sesuai dengan track yang akan diujikan..
\end{abstract}

Kata Kunci - Line Follower, Pemisah Warna, PID

\begin{abstract}
Line Follower Robot is an automated robot that can follow a line that is made using a dark -colored material (black) which is supported by a chain of electronics components are equipped with wheels and is moved by a motor. Speed control is very dependent on the brick and the friction between the tire rotation robot with the floor. The robot is designed to navigate and move automatically in response to a flow line made. To read the line, the robot is equipped with an optical sensor that is placed in front of the tip of the robot. Line Follower Robot has the type and shape and have some drive and control system as a regulator of diverse performance in accordance with the maker's creativity. In designing the project time line follower robot will be discussed on the object color separator and analyzed over a factor in the speed of movement of the robot with a motor that is controlled by the controller Proportional Integral Derivative (PID) so that the robot can move dynamical in accordance with a track that will be tested.
\end{abstract}

Keywords - Line Follower, Colour Separator, PID 


\section{PENDAHULUAN}

Perkembangan teknologi sekarang ini telah menciptakan berbagai kemajuan di bidang teknologi, khususnya teknologi di bidang robotika. Dalam perkembangannya, robot dapat digunakan dalam suatu industri, dengan adanya robot maka proses produksi dalam industri akan lebih cepat. Robot juga memiliki tingkat ketelitian yang tinggi jika dibandingkan dengan tenaga manusia. Robot dapat bekerja tanpa mengenal lelah sehingga akan membantu pekerjaan manusia. Robot juga dapat digunakan untuk mengangkat barang dan membawa barang secara otomatis, maka dengan adanya robot pengangkat barang secara otomatis, robot tersebut dapat menggantikan pekerjaan manusia dalam memindahkan atau mengangkat suatu barang secara manual.

Robot Line Follower merupakan salah satu bentuk sistem beroda yang yang dirangkai untuk menghasilkan jenis kendaraan yang berjalan secara otomatis dengan kecepatan tertentu untuk mengikuti sebuah garis. Maka dengan adanya robot yang dapat mengangkut benda secara otomatis tentu mengurangi bahaya terhadap pekerja dan pekerjaan akan lebih cepat. Dalam hal ini robot dapat mengenali benda berdasarkan warna dengan menggunakan Code Vision AVR sebagai pusat kendali. Robot akan mengelompokkan benda yang sejenis secara otomatis sesuai dengan track yang ditentukan.

Line Follower Robot atau disebut juga sebagai line tracer robot adalah robot yang dapat mengikuti garis/jalur. Garis atau jalur dibuat dengan menggunakan bahan yang berwarna gelap (hitam) misalnya lakban hitam, sedangkan daerah di sekitar jalur/lantai berwarna cerah (putih). Robot ini menggunakan IR sensor untuk mendeteksi jalur yang dibuat, yaitu dengan cara posisi robot diletakkan pada jalur, usahan posisi jalur hitam berada di tengah-tengah IR sensor kiri dan IR sensor kanan. (Sumber: Heri Andrianto.2013).

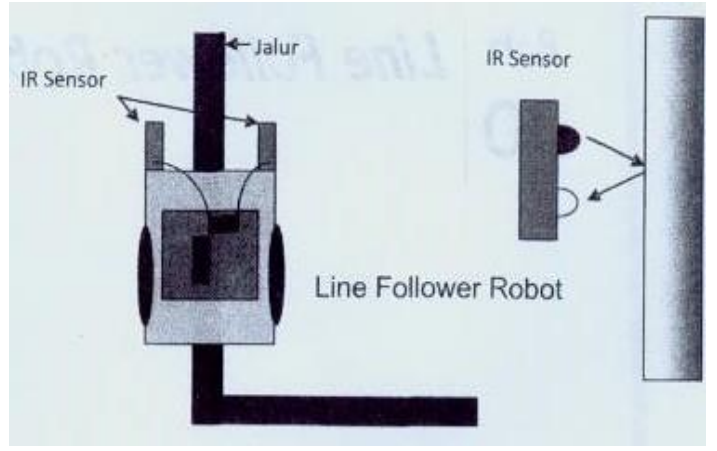

Gambar 1. Line Follower Robot

Secara garis besar, perancangan robot line follower pemisah benda berdasarkan warna dirancang menggunakan beberapa komponen yaitu yang terdiri dari: Sensor (Sensor Warna (RGB), Sensor Garis), Motor DC, Motor Servo, dan Mikrokontroler ATMega16.

\subsection{Sensor}

Sensor adalah peralatan yang digunakan untuk merubah suatu besaran fisik menjadi besaran listrik sehingga dapat dianalisa dengan rangkaian listrik tertentu. Sensor yang digunakan dalam perancangan alat ini yaitu sensor photodioda yang mampu menangkap gelombang cahaya yang dipancarkan oleh InfraRed.(Sumber : Ryandika Andricaprisona \& Wendy Cakra Nugroho. 2013)

\subsubsection{Sensor Warna}

Dalam sistem pedeteksi objek yang berwarna, Untuk mendeteksi warna objek, robot line follower ini dilengkapi oleh sebuah sensor warna led dan photodioda. Sumber cahaya dari 
photodioda akan menghasilkan cahaya, kemudian sumber cahaya akan diproses dalam pemroses sinyal yang akan diterima oleh ADC (Analog to Digital Converter) mikrokontroller.

Perancanganan rangkaian sensor warna ini menggunakan 3 buah photodioda dan 3 buah led berwarna sekaligus (Merah, Hijau, Biru). Hasil penelitian akan menunjukkan bahwa sensor warna ini memiliki tingkat keakuratan lebih dalam hal mendeteksi warna objek. Dapat dilihat pada gambar berikut:

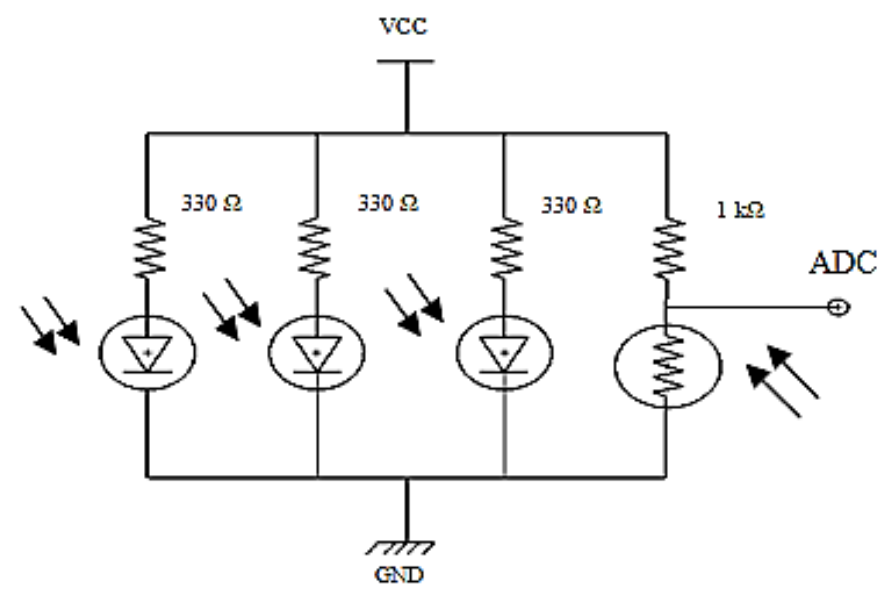

Gambar 2. Rangkaian Sensor Warna (RGB)

\subsubsection{Sensor Garis}

Untuk mendeksi sebuah garis, maka robot line follower dilengkapi dengan sensor pemancar cahaya, sensor ini mempunyai rangkaian yang sama dengan sensor warna, hanya penempatannya saja yang berbeda. Masing-masing sensor menggunakan sebuah led dan sebuah photodioda yang diletakkan di bawah rangkaian robot dan tepatnya saling berhadapan dengan garis. Sensor ini memanfaatkan pantulan led yang diterima oleh photodioda. Berikut rangkaian dari sensor garis :

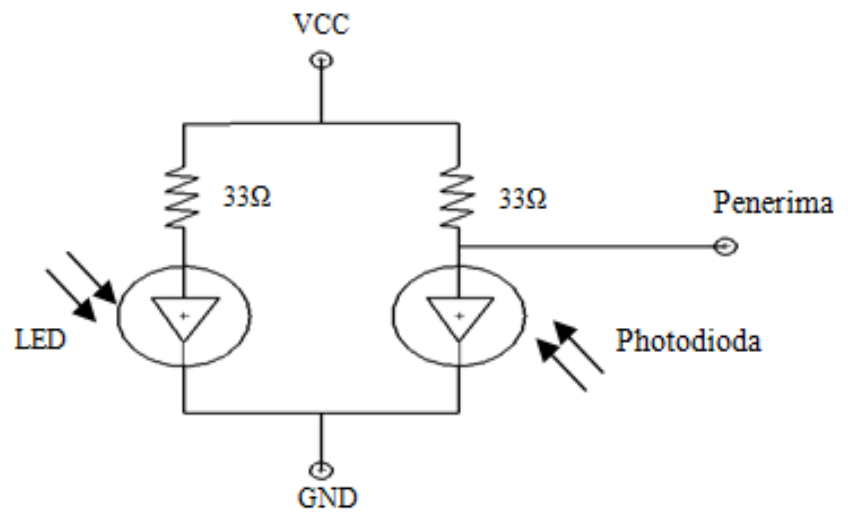

Gambar 3. Rangkaian Sensor Garis

\subsection{Motor DC}

Prinsip kerja motor DC didasarkan atas kumparan yang berarus listrik yang berada didalam medan magnet. Hubungan antara arus listrik dan arah gerakan kumparan dapat ditentukan dengan aturan tangan kiri. Kaidah tangan kiri menunjukan bahwa telunjuk tangan kiri menunjukkan arah yang sama dengan arah garis gaya, maka jari tengah menunjukkan arah arus, tetapi ibu jari menunjukkan kearah gerak kumparan, bagian- bagian dari motor DC terdiri 
dari komutator, sikat, angker dinamo, dan magnet permanen. Bagian- bagian motor DC dapat dilihat pada gambar berikut ini:

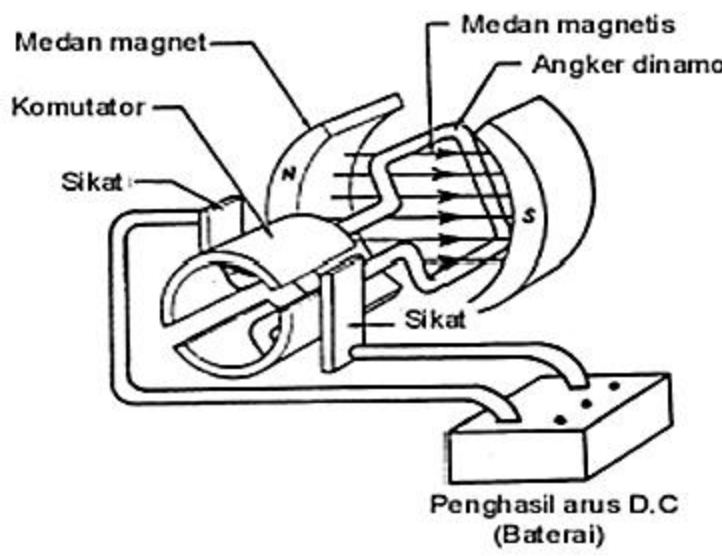

Gambar 4. Bagian Motor DC

(Sumber: Abdul Rahman Wahid \& Imam Al Haris. 2013)

\subsection{Motor Servo}

Motor servo adalah motor DC kualitas tinggi yang memenuhi syarat untuk digunakan pada aplikasi servo seperti closed control loop. Motor tersebut harus dapat menangani perubahan yang cepat pada posisi, kecepatan dan percepatan, serta harus mampu menangani intermittent torque. Sedangkan servo, adalah motor DC dengan tambahan elektronika untuk kontrol PW dan digunakan untuk tujuan hobist, pada pesawat terbang model, mobil atau kapal. Servo mempunyai 3 kabel, yaitu VCC, ground dan PW input. Tidak seperti PWM psds motor DC, input sinyal untuk servo tidak digunakan untuk mengatur kecepatan, tetapi digunakan untuk mengatur posisi dari putaran servo.

Motor servo standar dilengkapi dengan motor DC untuk mengendalikan posisi sebuah robot. Rotor motor dapat diputar/diposisikan hingga 180 derajat. Untuk motor servo continuous, dapat berputar hingga 360 derajat. Motor servo biasa digunakan untuk mengendalikan gerak dari toys (mainan) seperti model mobil, pesawat perahu, dan helikopter. Berikut contoh dari motor servo:

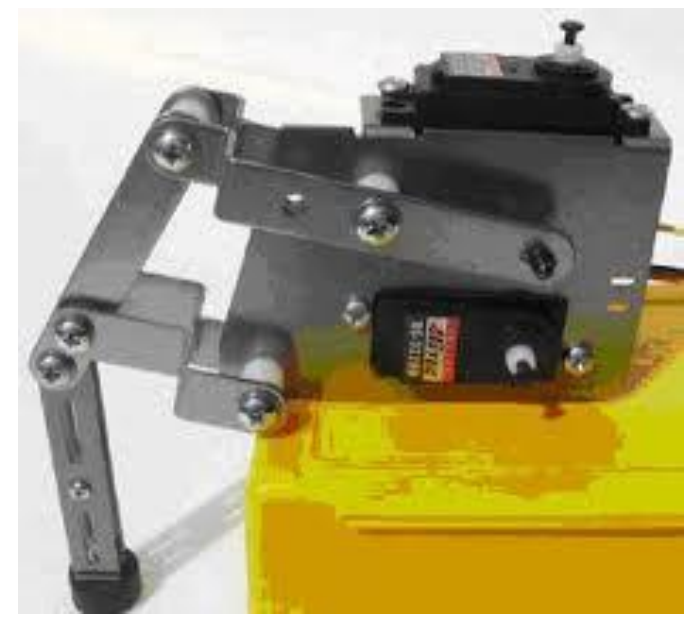

Gambar 5. Motor Servo

(Sumber: Widodo Budiharto. 2006) 


\subsection{Mikrokontroler ATMegal6}

Atmel Corporation (2010) dalam database ATmega16 menjelaskan, ATmega16 mempunyai dua memori utama yaitu memori data dan memori program, selain itu ATmega16 memiliki memori EEPROM untuk menyimpan data. ATmega16 juga memiliki 16 byte on-chip in system reprogrammable flash memory untuk menyimpan program. (Sumber: Heri Andrianto. 2013)

Didalam mikrokontroler ATmega16 terdiri dari:

a. Saluran I/O 32 buah, yaitu Port A, Port B, Port C, dan Port D.

b. ADC (analog to digital converter) 10 bit sebanyak 8 chanel.

c. Tiga buah timer/counter dengan kemampuan perbandingan.

d. CPU yang terdiri dari 32 register.

e. 131 instruksi anda, yang tentunya hanya membutuhkan 1 siklus.

f. Watchdog timer dengan oscillator internal.

g. Dua buah timer/counter 8 bit.

h. Satu buah timer/counter 16 bit.

i. Tegangan operasi 2,7-5,5 $\mathrm{V}$ pada ATmega16

j. Internal SRAM sebesar 1KB.

k. Memory sebesar 16KB dengan kemampuan red while red.

1. Unit interupsi internal dan eksternal.

m. Port antarmuka SPI.

n. EEPROM sebesar 512 byte dapat di program saat operasi.

o. Antarmuka komperator analog.

p. 4 chanel PWM.

q. $32 \times 8$ general register.

r. Hampir mencapai16 MIPS.

s. Port USART programmable untuk komunikasi serial.

Berikut ini merupakan wujud dari gambar mikrokontroler ATMega16 pada gambar berikut ini:
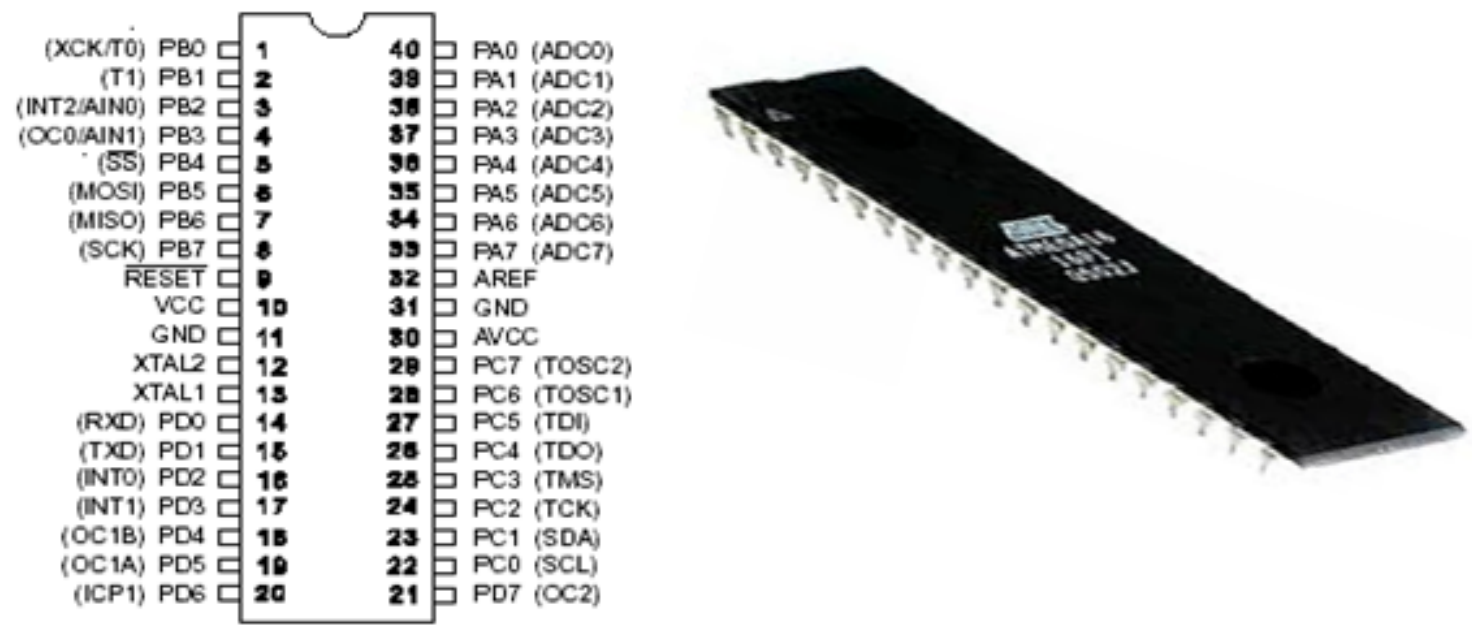

Gambar 6. Mikrokontroler ATMega16

Fitur-fitur yang dimiliki oleh Mikrokontroler Atmega16 adalah sebagai berikut:

1. Mikrokontoller AVR 8 bit yang memiliki kemampuan tinggi, dengan daya rendah.

2. Arisitektur RISC dengan throughput mencapai $16 \mathrm{MIPS}$ pada frekuensi $16 \mathrm{MHz}$.

3. Memiliki kapasitas Flash memori 16 Kbyte, EEPROM 512 Byte dan SRAM 1 Kbyte.

4. Saluran I/O sebanyak 32 buah, yaitu Port A, Port B, Port C, dan Port D.

5. CPU yang terdiri atas 32 buah register. 
6. Unit interupsi internal dan eksternal.

7. Port USART untuk komunikasi serial.

8. Fitur Peripheral

a. Tiga buah Timer/Counter dengan kemampuan perbandingan.

- 2 (dua) buah Timer/Counter 8 bit dengan Prescaler terpisah dan Mode Compare.

- 1 (satu) buah Timer/Counter 16 bit dengan Prescaler terpisah, Mode Compare, dan Mode Capture.

b. Real Time Counter dengan Oscillator tersendiri.

c. 4 Channel PWM

d. 8 Channel, 10-bit ADC

- 8 Single-ended Channel

- 7 Differential Channel hanya pada kemasan TQFP

- 2 Differential Channel dengan Programmable Gain 1x, 10x, atau 200x

e. Byte-oriented Two-wire Serial Interface

f. Programmable Serial USART

g. Antarmuka SPI

h. Watchdog Timer dengan oscillator internal.

i. On-chip Analog Comparator

\subsection{Bahasa C}

Software atau perangkat lunak merupakan salah satu komponen utama dalam sistem mikrokontroler. Kerja mikrokontroler bergantung dari software yang telah ditanam di dalam memorinya. Software mikrokontroler berup rangkaian instruksi yang diprogram sesuai keinginan programmer. Bahasa pemrograman $\mathrm{C}$ merupakan bahasa pemrograman tingkat tinggi, yang instruksinya mudah untuk dipahami. Bahasa ini banyak digunakan dalam pemrograman komputer untuk membuat software perkantoran, database, antarmuka komputer dengan perangkat tambahan, serta banyak aplikasi lainnya. Beberapa keuntungan penggunaan bahasa $\mathrm{C}$ dibandingkan assembler:

1. Lebih cepat dalam implementasi software karena operasi yang panjang dengan bahasa assembler bisa ditulis lebih pendek dan lebih mudah dengan bahasa $\mathrm{C}$.

2. Instruksi bahasa $\mathrm{C}$ tidak sebanyak assembler dan mudah diingat.

3. Kita tidak di sibukkan dengan pengalokasian variabel ke register- register mikrokontroler.

4. Program yang sama bisa digunakan oleh banyak tipe mikrokontroler karena banyak vendor yang membuat compiler $\mathrm{C}$.

5. Alur program lebih mudah dipahami dan di modifikasi bahkan oleh programmer lain.

6. Banyak orang yang menggembangkan software dengan bahasa $\mathrm{C}$ sehingga banyak referensi program bila dibutuhkan.

7. Bahasa $\mathrm{C}$ bisa dikombinasikan dengan bahasa assembler bila dibutuhkan. (Sumber: Bagus Hari Sasongko. 2012)

\section{METODE PENELITIAN}

Agar dapat melihat struktur jalannya program maka dibuat flowchart (diagram alur). Flowchart digunakan sebagai dasar acuan dalam membuat program. Struktur program akan lebih mudah dibuat/didesain.Selain itu juga jika terdapat kesalahan akan lebih mudah untuk mendeteksi letak kesalahannya serta untuk lebih memudahkan dalam menambahkan instruksiinstruksi baru pada program jika nantinya terjadi pengembangan pada struktur programnya. Prinsip kerja dari perancangan robot line follower pemisah benda berdasarkan warna dapat digambarkan menggunakan flowchart sederhana seperti di bawah ini: 
Citec Journal, Vol. 1, No. 3, Mei 2014 - Juli 2014

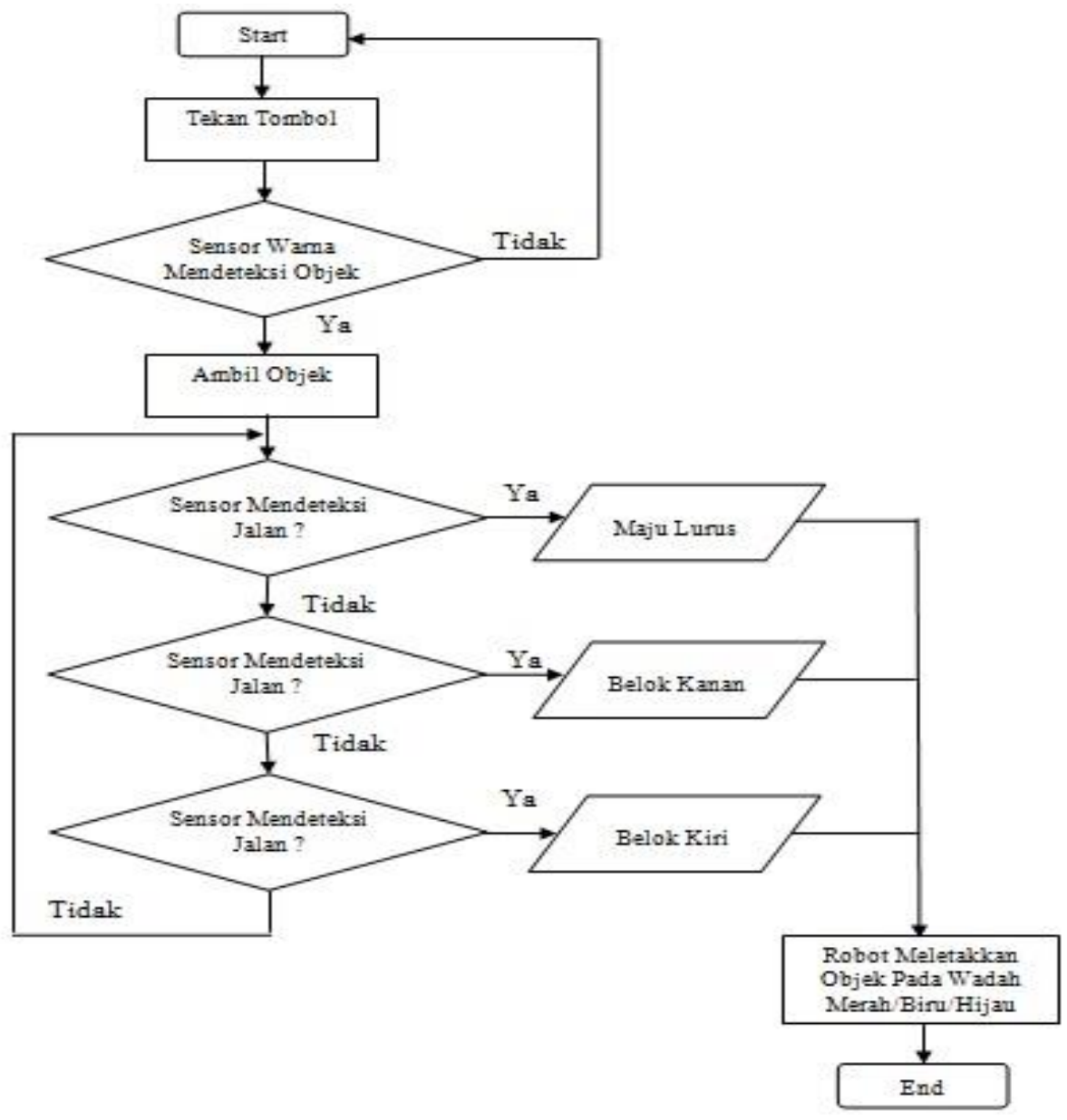

Gambar 7. Flowchart Perancangan Robot Line Follower Pemisah Benda Berdasarkan Warna

\section{Penjelasan Flowchart:}

Program diawali dengan start, yang berarti bahwa rangkaian robot telah diaktifkan. Selanjutnya program akan dikendalikan oleh tombol (button) untuk menghidupkan laju robot, kemudian sensor warna akan bekerja dengan cara mendeteksi warna objek dan akan menampilkan warna pada LCD .Motor Servo kemudian bekerja sebagai penjepit objek. Jika objek telah dibawa oleh robot, maka robot akan berjalan dan mendeteksi arah jalur garis dengan sensor .Apabila robot tidak berhasil mendeteksi arah jalur garis maka robot akan terus mendeteksi sampai arah jalur garis yang benar. Setelah robot menemukan arah jalur garis yang benar maka robot akan mendeteksi wadah yang telah ditentukan dan meletakkan objek pada wadah yang disediakan berdasarkan warna yang telah ditentukan. Selanjutnya program akan mengulang kembali ke awal untuk kembali mengambil objek dari masing- masing warna.

Secara garis besar, perancangan robot line follower pemisah benda berdasarkan warna ini terdiri dari Sensor, Motor Servo, Motor DC, Catu Daya, LCD 16x2, Pust Button, minimum sistem mikrokontroler ATMEGA16. Berikut ini adalah diagram blok dari simulasi perancangan robot line follower pemisah benda berdasarkan warna dapat dilihat pada gambar berikut ini: 


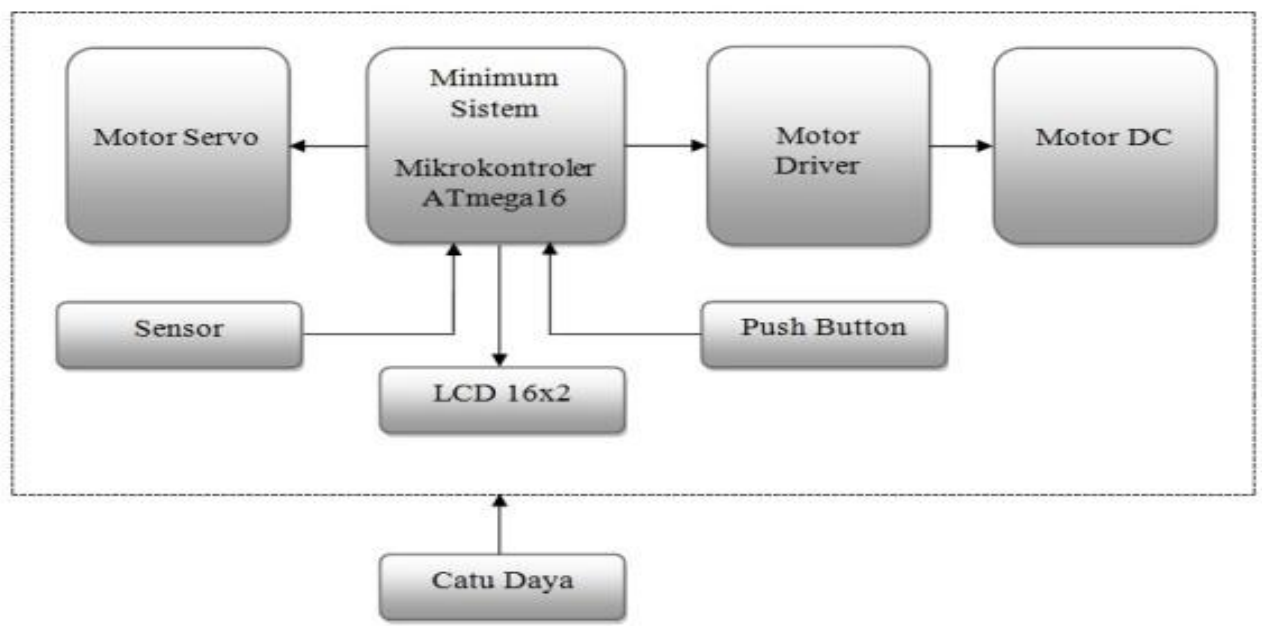

Gambar 8. Digram Blok Rangkaian

\section{Penjelasan Blok Diagram:}

1. Minimum sistem ATMEGA16 merupakan pusat kendali dari seluruh rangkaian.

2. Catu Daya yang digunakan yaitu baterai yang berfungsi sebagai sumber tegangan.

3. Sensor yang digunakan adalah sensor garis (photodioda) yaitu sebagai pendeteksi arah jalur garis, dan RGB (Red, Green, Blue) sebagai sensor pedeteksi objek (benda).

4. Driver motor berfungsi untuk mengendalikan laju dan mundur motor pada rangkaian.

5. Motor DC digunakan sebagai alat pemutar laju roda robot line follower.

6. Motor Servo berfungsi sebagai alat penggerak untuk menjepit objek (benda).

8. Push Button digunakan sebagai tombol on/off untuk menjalankan atau mematikan laju robot.

9. LCD 16x2 sebagai tampilan data secara hardware.

\section{HASIL DAN PEMBAHASAN}

Setelah semua rangkaian yang telah selesai dirancang pada perancangan robot line follower pemisah benda berdasarkan warna, maka berikut ini adalah gambar hasil dari perancangan, dapat ditunjukan oleh gambar di bawah ini:

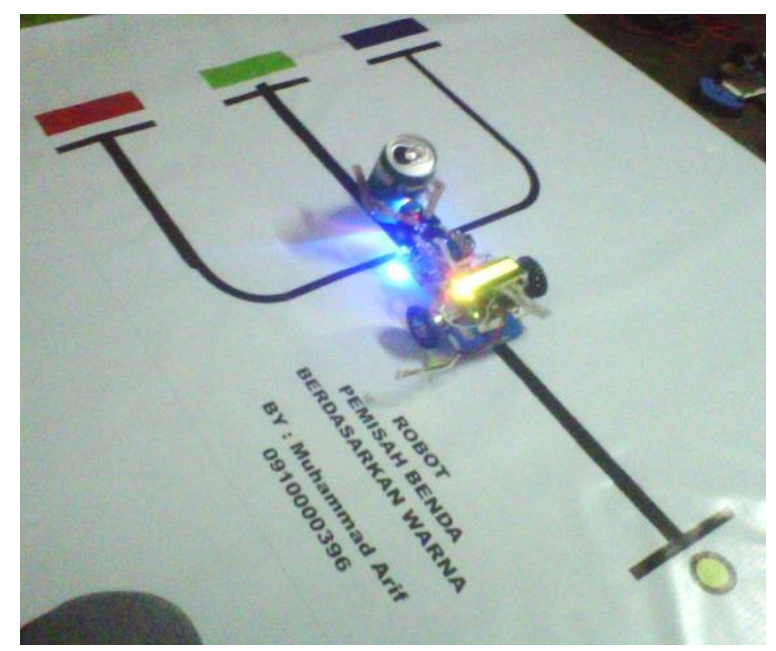

Gambar 9. Keseluruan dari hardware 


\subsection{Pengujian Rangkaian Mirkokontroler ATMegal6}

Untuk mengetahui apakah rangkaian mikrokontroler ATMega16 telah bekerja dengan baik, maka dilakukan pengujian. Pengujian bagian ini dilakukan dengan memberikan program sederhana pada mikrokontroler ATMega16 Programnya adalah sebagai berikut:

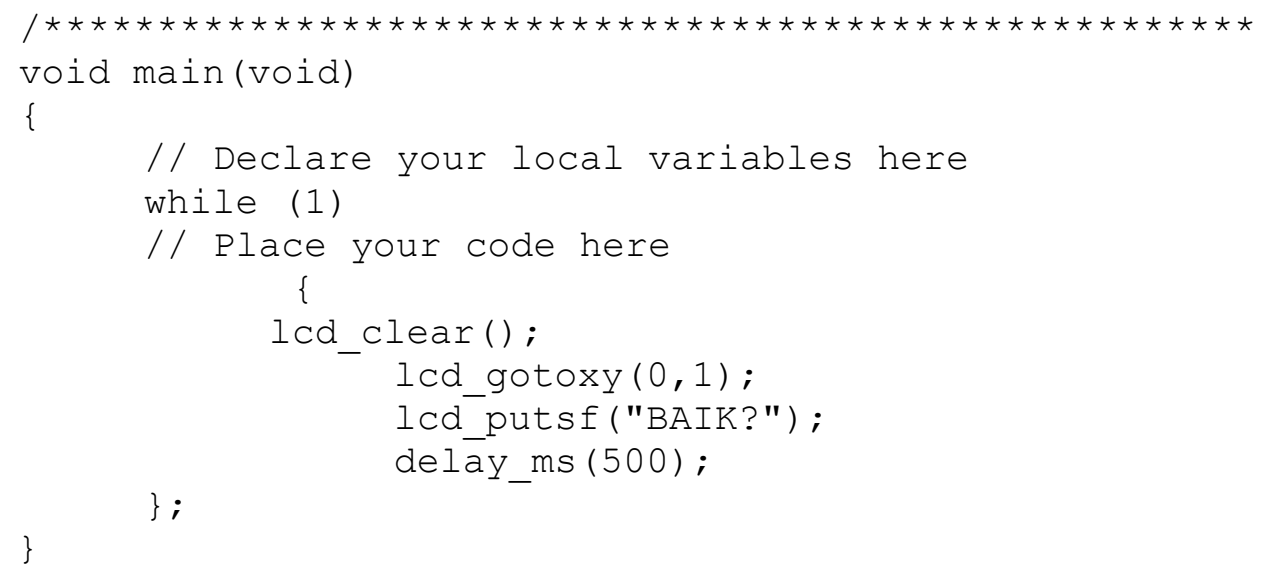

Program di atas bertujuan untuk menampilkan tulisan "TEST" di LCD 16x2 yang terhubung ke mikrokontroler melalui PORTC. Apabila LCD 16x2 menampilkan tulisan "BAIK?" seperti tulisan diatas, maka rangkaian minimum mikrokontroler ATMEGA16 telah bekerja dengan baik.

\subsection{Pengujian Perangkat}

Sebelum perangkat perancangan robot line follower pemisah benda berdasarkan warna berbasis mikrokontroler ATMEGA16 digunakan, perangkat harus dihubungkan dengan sumber tegangan untuk berkerja. Setelah perangkat dihidupkan, perangkat akan langsung menampilkan nilai warna RGB (Red, Green, Blue) pada LCD. Berikut adalah gambar tampilan awal sebelum mendeteksi benda yang telah ditentukan, ditunjukan pada gambar 10 berikut:

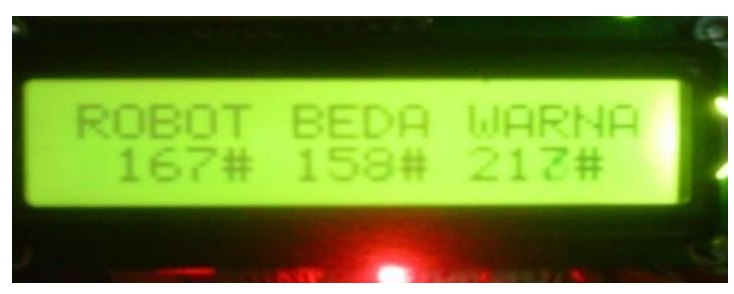

Gambar 10. Perangkat Pada Awal Dijalankan

Kemudian setelah perangkat dijalankan, perangkat akan langsung mendeteksi warna objek yang telah disediakan. Setelah itu perangkat akan menampilkan warna objek pada LCD. Berikut adalah gambar tampilan saat mendeteksi benda yang telah ditentukan:

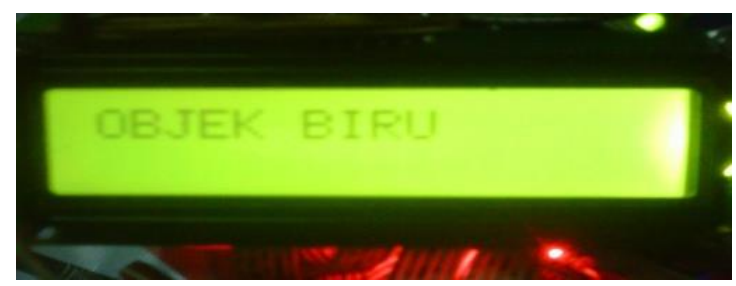

Gambar 11. Perangkat Saat Mendeteksi Objek Biru 


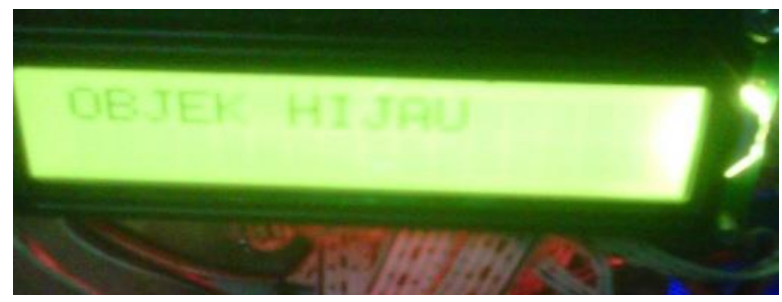

Gambar 12. Perangkat Saat Mendeteksi Objek Hijau

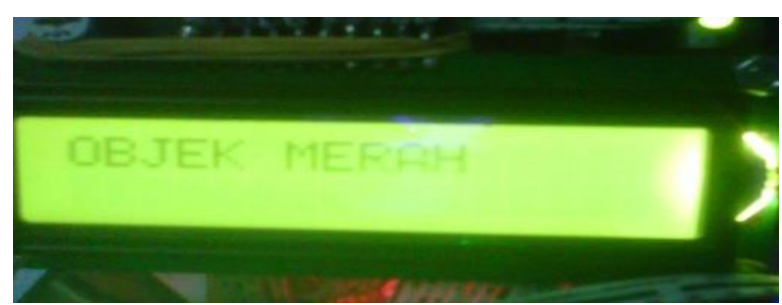

Gambar 13. Perangkat Saat Mendeteksi Objek Merah

Jika sensor warna RGB mendeteksi objek yang disediakan, maka perangkat akan langsung mengambil objek dan robot akan menampilkan warna objek pada LCD yang dideteksi oleh sensor warna RGB, kemudian robot akan membaca jalur garis dan membawa objek warna pada wadah yang telah ditentukan sesuai warna pada objek. Berikut adalah gambar dari tampilan perangkat robot saat meletakkan objek pada wadah yang disediakan, ditunjukan pada gambar berikut:

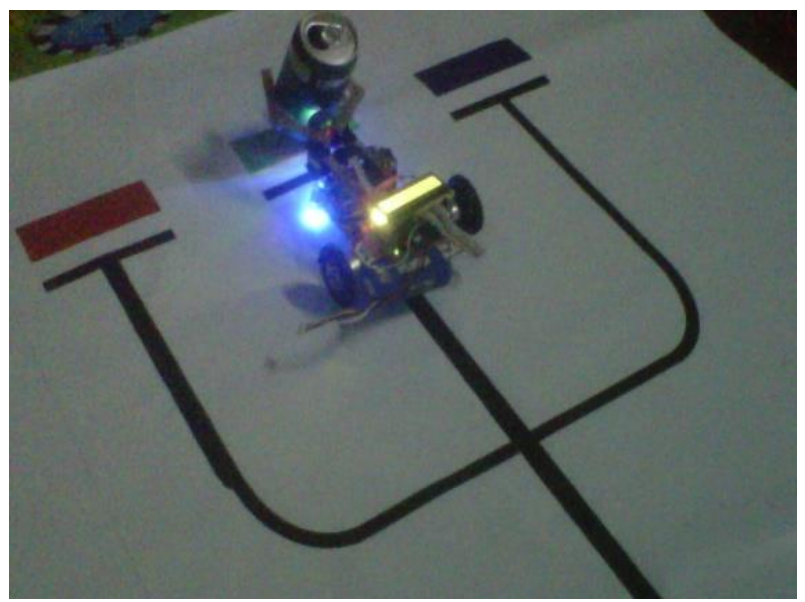

Gambar 14. Robot Meletakkan Objek

Kemudian robot akan kembali pada start awal untuk mengambil objek warna yang lain dan robot akan meletakkan objek yang lain pada wadah atau tempat yang telah ditentukan. Kemudian robot akan trus menerus mengulang untuk mengambil dan menempatkan objek. Berikut adalah tabel nilai warna yang digunakan:

Tabel 1. Nilai warna

\begin{tabular}{|c|l|c|}
\hline NO & WARNA & NILAI WARNA \\
\hline 1 & Merah & red $>130 \& \&$ green $>130=$ merah \\
\hline 2 & Hijau & red $>150 \& \&$ green $>120 \& \&$ bule $>170=$ hijau \\
\hline 3 & Biru & red $<130 \& \&$ green $<130=$ biru \\
\hline
\end{tabular}




\section{Penjelasan Nilai Warna:}

1. Jika nilai warna merah $>130$ dan nilai warna hijau $>130$ maka sensor warna pada robot akan menyatakan warna merah pada benda.

2. Jika nilai warna merah $>150$ dan nilai warna hijau $>120$ serta nilai warna biru $>170$ maka sensor warna pada robot akan menyatakan warna hijau pada benda.

3. Jika nilai warna merah $<130$ dan nilai warna hijau $<130$ maka sensor warna pada robot akan menyatakan warna biru pada benda.

\section{KESIMPULAN}

Pengujian pada penelitian yang telah dilakukan, dapat disimpulkan bahwa alat serta sistem yang telah dibangun dapat diaplikasikan pada sebuah industri untuk digunakan sebagai pengangkut benda dengan menggunakan mikrokontroler sebagai alat pengatur gerak dari motor servo untuk mengambil dan memindahkan objek benda berdasarkan warna dengan menggunakan baterai sebagai sumber tegangan sehingga dapat berjalan secara otomatis tanpa adanya operator.

\section{SARAN}

1. Dalam Penelitian ini Robot masih merupakan robot simulasi, untuk pengembangan lebih lanjut robot ini bisa digunakan untuk industri pengemasan barang.

2. Sebaiknya robot lebih kepada menerapkan kecerdasan dalam menentukan objek - objek dengan warna yang lebih akurasi dalam membaca intensitas warna dengan menggunakan metode yang berbeda

\section{DAFTAR PUSTAKA}

[1] Andricaprisona, R., Nugroho, W. C., 2013, Prototype Penampil Kapasitas Parkir Mobil Berbasis Mikrokontroler, Jurnal Himpunan Ahli Diploma 3 Teknik Elektronika Universitas Negeri Jakarta (HAD3ELKA), Vol 98, No 1, hal 15.

[2] Wahid, A. R., Haris, I. A., 2013, Prototype Water Lavel Control Berbasis Mikrokontroler, Jurnal Himpunan Ahli Diploma 3 Teknik Elektronika Universitas Negeri Jakarta (HAD3ELKA), Vol 98, No 1, hal 1-14.

[3] Budiharto, W., 2006, Belajar Sendiri Membuat Robot Cerdas, PT. Elex Media Komputindo, Jakarta.

[4] Andrianto, H., 2013, Pemrograman Mikrokontroller AVR ATmegal6 Menggunakan Bahasa $C$ (edisi revisi), Informatika, Bandung.

[5] Sasongko, B. H., 2012, Pemrograman Mikrokontroller dengan Bahasa C, Andi Offset, Yogyakarta. 